\title{
INDONESIAN COVID-19 PREVENTION POLICIES ANALYSIS USING CUMULATIVE CASES DATA REGRESSION
}

\author{
Bhustomy Hakim and Akhmat Fauzi \\ Harbin Institute of Technology \\ bhustomy.hakim@gmail.com, akhmatfauzi I2@gmail.com
}

\begin{abstract}
The emergence of severe acute respiratory syndrome coronavirus 2 (SARS-CoV-2) or called COVID-19 which occurred in China at the end of 2019 has become a global public health problem. Indonesia government made and apply some public health prevention policy against coronavirus outbreak. They applied their first big scale social distancing (PSBB policy) that order people to stay, work, study, and pray at home. Indonesia government also warned people not to travel through outer city due to Eid Al-Fitr, Islamic big annual event, (MUDIK policy) which usually lead people to travel through the cities to meet their family to celebrate. Indonesian PSBB policy has flattened $7.30 \%$ of the curve according to the prediction of situation with and without PSBB. But for MUDIK policy, it seems people get scared of they couldn't make it to cross the city to meet their family and travel instead then make the spreading of the cases were increased. The publishing move of the policy also should be calculated, because people will take future act regarding to the information they get.
\end{abstract}

Keywords: COVID-19, Indonesia, Policy, Regression Analysis, Pandemic, Coronavirus, Social Distancing, Lockdown.

Received 25 Mei 2020 Accepted 6 February 2021

\section{INTRODUCTION}

The world is currently experiencing a global pandemic that called coronavirus disease 2019, or as well-known as COVID-19. This outbreak was triggered since December 2019 in Wuhan city, Hubei province of China and continues to spread across the world ${ }^{[1]}$. As of 15 May 2020 COVID-19 has infected 216 countries and territories around the world and has become a major global health concern ${ }^{[2]}$. SARS-CoV-2 was found to be a positive-sense, singlestranded RNA virus belonging to the genus Betacoronavirus ${ }^{[3]}$. Based on the large number of people infected by COVD-19, it shows that the trend of increasing incidents largely follows exponential growth with the number (R0) estimated to range from 2 to 3 , indicating that one patient could transmit the disease to two to three other people, ${ }^{[5-6]}$ which was higher than SARS and MERS. The current estimate of the maximum incubation period for COVID-19 is 14 days, with potential asymptomatic transmission ${ }^{[7]}$. A study from Vo'Euganeo, $50 \mathrm{~km}$ west of Venice, Italian village showed majority of people infected with covid-19 (50\% to 75\%) were considered asymptomatic or mild pneumonia but released large amounts of viruses at the early phase of infection, which posed enormous challenges for containing the spread of COVID-19 ${ }^{[8]}$.

In the last twenty years itself, the world has experienced global public health crisis such as the severe acute respiratory syndrome such as the outbreak of severe acute respiratory syndrome coronavirus (SARS-CoV) in 2002-2003 [9], influenza pandemic (H1N1) in $2009^{[10]}$, Middle East respiratory syndrome coronavirus (MERS-CoV) in 2012 [11] and Ebola virus diseases in 2014-2016 ${ }^{[12]}$. However, the COVID-19 pandemic revealed that we were 
still not ready to face a new virus outbreak that could spread suddenly and quickly. It made economy caught in chaos. As a result of the pandemic, the global economy is projected to decline sharply by 3 percent in 2020, much worse than during the crisis of financial in 2008 $2009^{[13]}$. Regarding to the lack of knowledge of the virus, many government made and apply some public health prevention policy based on government of former country who got handling it in the first wave of pandemic which might make the pandemic disaster slowly decreasing and make the people safe.

Indonesia as the fourth most populous country in the world, is predicted to suffer greatly in a longer period of time due to COVID-19, compared to other less densely populated countries ${ }^{[14]}$. Indonesia did not report any cases of infection at all when China was struck the SARS-CoV 2 during the months of December 2019 - February 2020. Then on March 2 2020, President of Indonesia, Joko Widodo, reported the first confirmed two cases of COVID-19 infection in Indonesia. As of May 13, the country has reached 15,438 confirmed cases, 689 new cases, with 1,028 cases of deaths, and 3,287 cases of recoveries ${ }^{[14,15]}$. After the first confirmed case announcement, it took about 20 days to get Indonesia in national emergency status and the government's rapid test program started. On 30th March 2020, Indonesia applied their first big scale social distancing (PSBB policy) that order people to stay, work, study, and pray at home. The government also warned people not to travel through outer city due to Eid Al-Fitr, Islamic big annual event, (MUDIK policy) which usually lead people to travel through the cities to meet their family to celebrate. The policy itself was officially begun on 24th April 2020 ${ }^{[15]}$.

This paper is one of the first academic publications focused on Indonesian policy responses aimed at providing a brief reporting, analysis and evaluation of the current rapid response to COVID-19 that was carried out by analyzing the cumulative statistical modeling of COVID-19 cases. So we can find the effect of the relationship between the number of cases and the policies taken by the Indonesian government. Our analysis can capture the current government-led response amid a coronavirus outbreak. This paper can be viewed as 'real-time evaluation' as it provides insights and lessons for all stakeholders to improve and adjust existing policy options mainly at national level.

\section{RESEARCH METHOD}

The number of COVID-19 contracted persons from 2 March 2020 to 12 May 2020 is scaled to get the number of cumulative cases and plotted versus the number of days of the virus spread as the dataset using python 3.7. The data is based from kaggle.com ${ }^{[16]}$. The least square polynomial regression of degree two method is determined as statistical model for analysis each region so that the results are validated and interpreted. The modeling function can be found by stating matrix of $G$ which $G=A^{T} x A$, where $A$ is number of cumulative of day by day from 2 March to 12 May 2020. Then state vector $\left\{\mathrm{y}_{0}, \mathrm{y}_{1}, \mathrm{y}_{2}\right\}$ which $\left\{\mathrm{y}_{0}, \mathrm{y}_{1}, \mathrm{y}_{2}\right\}=A^{\mathrm{T}} \mathrm{x} B$, where $\mathrm{B}$ is the number of cumulative cases. So the coefficients of modeling can be discovered in this formula ${ }^{[17]}$ :

$$
\mathrm{f}=\mathrm{a}_{0}+\mathrm{a}_{1} \mathrm{x}+\mathrm{a}_{2} \mathrm{x}^{2}, \text { where }\left\{\mathrm{a}_{0}, \mathrm{a}_{1}, \mathrm{a}_{2}\right\}=\mathrm{G}^{\prime} \cdot\left\{\mathrm{y}_{0}, \mathrm{y}_{1}, \mathrm{y}_{2}\right\}
$$

By using the modeling function, the model of predicted number of cases will be set. Then, the modeling data curves will be plotted side by side with the real data curve. And for modeling function of prediction condition without PSBB, the dataset is being manipulated like Indonesia didn't take PSBB as one of their policy.

And $\mathrm{R}^{2}$ score has been calculated by defining as:

$$
R^{2}=1-\frac{S S E}{S S T O}
$$


Where SSE is the residual sum of squares and SSTO is total sum of squares[17]. A model of $\mathrm{R}^{2}$ is indicating that one variable dependency would have a high level of linear association with the two independent of variables.

\section{FINDINGS AND DISCUSSION}

The actual data and the modeling of predicted data are sketched in Figure. 1. The modeling function of the polynomial of degree two and the $\mathrm{R}^{2}$ values are displayed on the graph as well. This dataset in the modeling function shows that $\mathrm{R}^{2}$ values result is 0.9990 means the modeling of predicted data is $99.90 \%$ similar to the actual data given which is good enough to be used as validation of analysis of the performance of Indonesian policy as a response to the COVID-19 pandemic due to number of cases over time.

Indonesian Policies Analysis Graph

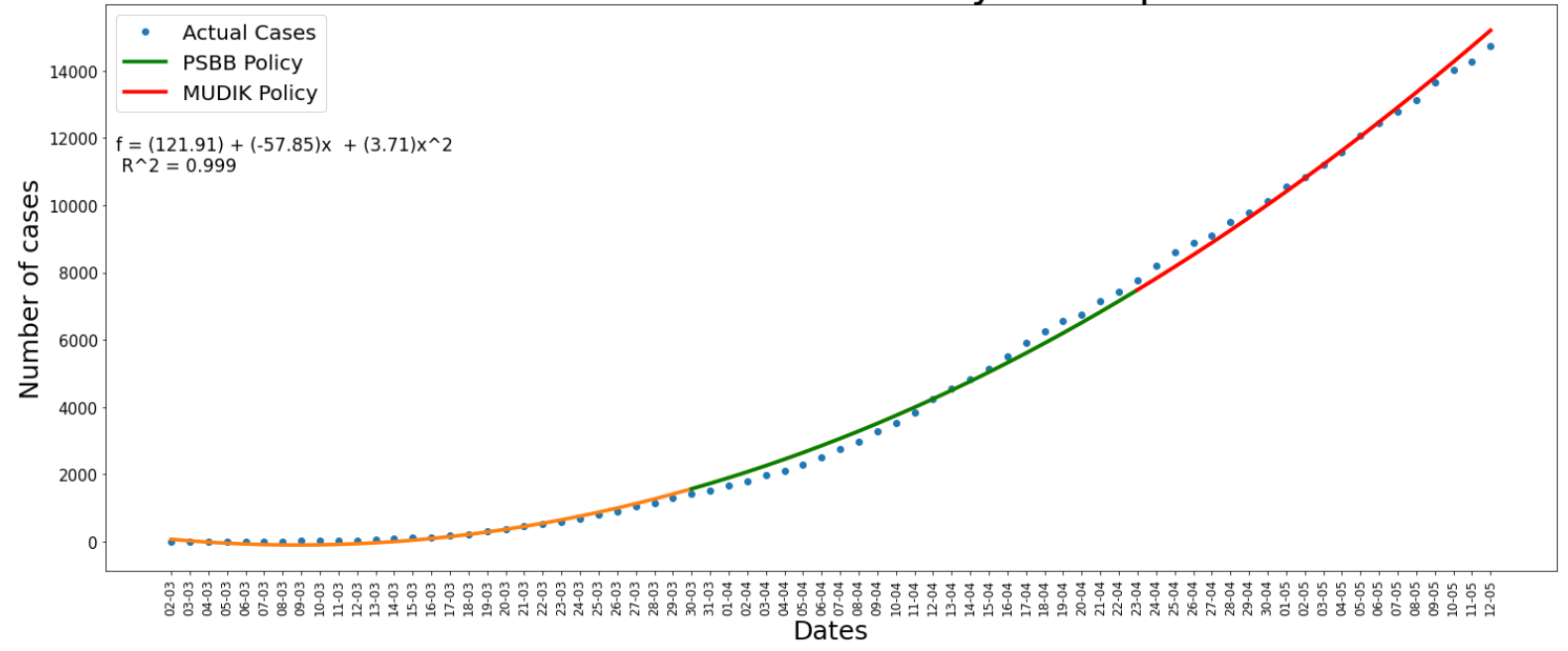

Figure 1. Correlations between Modeling and Real Data Curve Graph in Indonesia

By seeing Figure 1, per 30 March 2020 when PSBB policy has begun, the actual cases are showing difference to the modeling cases. For few days before and almost two weeks after, they were decreasing at the rate of $10.92 \%$. It means, from the announcement of the national emergency status to PSBB policy has applied, the spread of the novel coronavirus has been slowed down in Indonesia by this policy, so the people aware of it.

But on 15 April 2020, it seemed that the actual cases were increased. According to the timeline in Indonesia, the news of restriction of crossing city (MUDIK policy) will start on 24 April 2020 was published week before the policy date, so people might travel outer cities before 24 April 2020 [15] and the number of cases in about week before also after 24 April 2020 were increasing to $3.16 \%$. All the analysis has been made before and after the policy starts because the confirmation of the case takes time for at least 10 to 14 days.

As comparison, analysing of what happen in Italy also has been done in this paper. Italy is one of the countries who got infected the most by this new coronavirus pandemic, until 12 May 2020, it has been recorded there are approximately 200.000 cases. The number of new cases each day was growing rapidly. Even at first on last February, Italy had only few cases, but after it was getting serious then the government took Lockdown policy to prevent more spreading on 9 March 2020. It has been reported that massive people moving occurred one night before lockdown started. More than 1000 people were traveling across the region in Italy from the epicentrum of the pandemic that time.

Modeling function of the cumulative cases in Italy also has been set and its written in Figure 2. The $\mathrm{R}^{2}$ score for this model is 0.988 . By seeing Figure 3, few days after Lockdown policy had been announced, the number of cases is decreasing by $11.31 \%$. But the number of cases is increasing with the rate of $5.984 \%$ afterwards. 


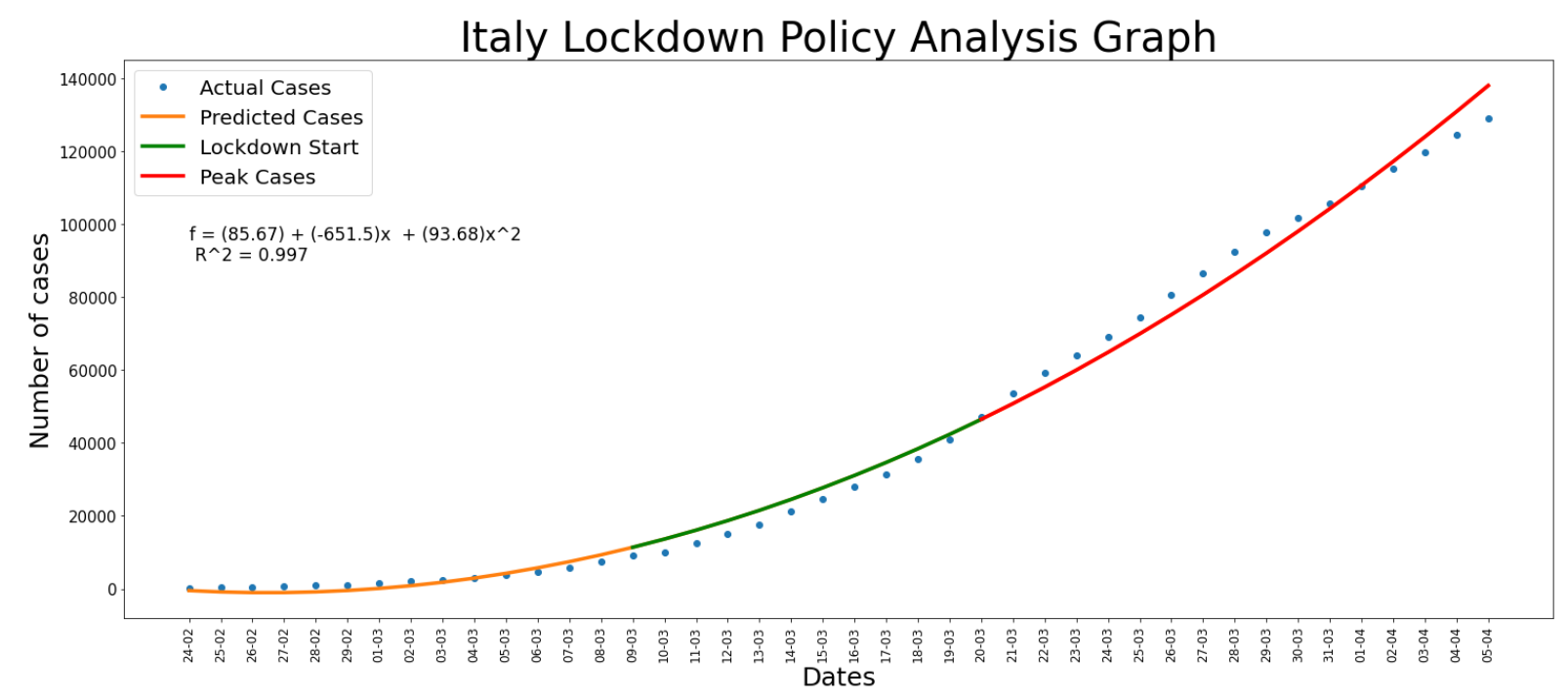

Figure 2. Correlations between Modeling and Real Data Curve Graph in Italy

It is shown that the Figure 1 and Figure 2 have similarity. Few days after the policy has been started, it is decreasing first, and then showing escalation for days in number of cumulative cases. It might because of the state whether someone is positive or not takes time and it has proven that the mass of people might go outside such as doing traveling back home, or buying some foods and things to prepare before doing the big social distancing or lockdown policy.

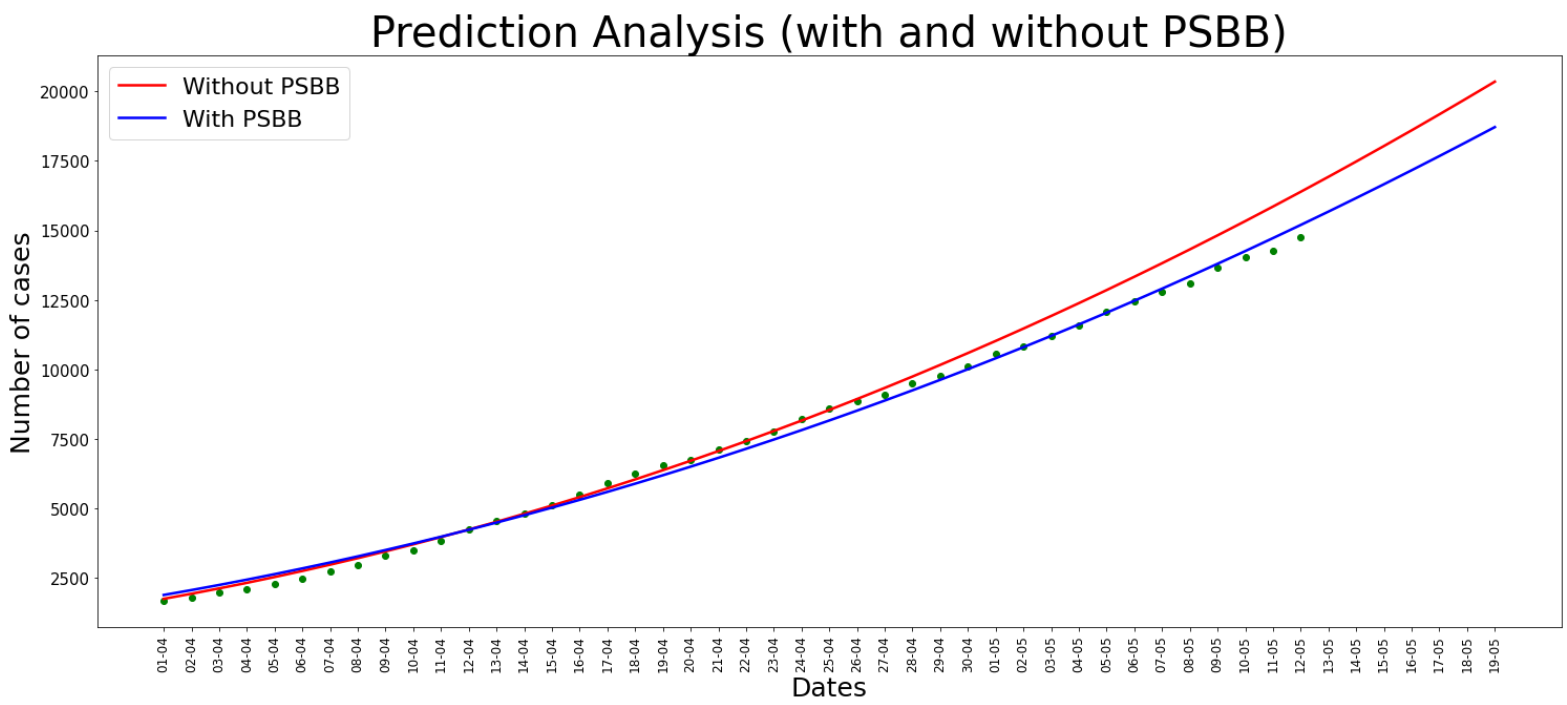

Figure 3. Polynomial modeling of with and without PSBB curve graph

This paper also interpreted prediction of Indonesian situation with and without PSBB which has plotted in Figure 3. Indonesian PSBB policy has flattened $7.30 \%$ of the curve according to the prediction of situation with and without PSBB.

\section{CONCLUSION}

Indonesian government took a good step in PSBB policy which could control people stay at home and not spreading COVID-19 for a moment which caused the curve flattened $7.30 \%$. But for MUDIK policy, it seems people get scared of they couldn't make it to cross the city to meet their family and travel instead then make the spreading of the cases were increased. The publishing move of the policy also should be calculated, because people will take future act 
regarding to the information they get. This behaviour is happened both in Indonesia and Italy. The upcoming policy that Indonesia takes due to this pandemic should be precisely proper so that the curve of the number of cases keeps flattening until the pandemic hopefully end.

\section{ACKNOWLEDGEMENTS}

Thanks to all those who have supported and contributed, so this research can be done and completed. Hopefully this research can be useful and more open to discuss.

\section{REFERENCES}

[1] C. Wang, P.W. Horby, F.G. Hayden, G.F. Gao, A novel coronavirus outbreak of global health concern, J. Lancet. 395 (2020) 470-473. https://doi.org/10.1016/S01406736(20)30185-9

[2] World Health Organization (WHO). Coronavirus disease (COVID-19) outbreak situation. https://www.who.int/emergencies/diseases/novel-coronavirus-2019. [accessed 15 May 2020].

[3] J.F. Chan, K.H. Kok, Z. Zhu, H. Chu, K.K. To, S. Yuan, et al., Genomic characterization of the 2019 novel human-pathogenic coronavirus isolated from a patient with atypical pneumonia after visiting Wuhan, J. Emerg. Microbes Infect. 9 (2020) 221-236. https://doi.org/10.1080/22221751.2020.1719902

[4] Q. Li, X. Guan, P Wu, et al., Early transmission dynamics in Wuhan, China, of novel $\begin{array}{lllll}\text { coronavirus- infected pneumonia. N } & \text { Engl J }\end{array}$ https://doi.org/10.1056/NEJMoa2001316

[5] J.T. Wu, K. Leung, G.M. Leung, Nowcasting and forecasting the potential domestic and international spread of the 2019- nCoV outbreak originating in Wuhan, China: a modelling study. Lancet. 395 (2020) 689- 697. https://doi.org/10.1016/S01406736(20)30260-9.

[6] Y. Liu, A.A. Gayle, A.S. Wilder, J. Rocklov. The reproductive number of COVID- 19 is higher compared to SARS coronavirus. J. Travel Med. 27 (2020), https://doi.org/10.1093/jtm/taaa021

[7] J.A Backer, D. Klinkenberg, J. Wallinga, Incubation period of 2019 novel coronavirus (2019-nCoV) infections among travellers from Wuhan, China, 20-28 January 2020. Euro Surveill. 25 (2020). doi: 10.2807/1560-7917.ES.2020.25.5.2000062.

[8] M. Day, Covid-19: identifying and isolating asymptomatic people helped eliminate virus in Italian village, BMJ. 368 (2020), doi: https://doi.org/10.1136/bmj.m1165.

[9] World Health Organization. Emergencies preparedness, response. Summary of probable SARS cases with onset of illness from 12002 to 31 July 2003. http://www.who.int/csr/sars/country/table2004_04_21/en/. [Accessed 16 May 2020].

[10] World Health Organization Emergencies preparedness, response. Pandemic (H1N1) 2009 - update 112 (2010). http://www.who.int/csr/don/2010_08_06/en/index.html. [Accessed 15 May 2020]

[11] X. Chen, A.A. Chughtai, A. Dyda, C.R. MacIntyre, Comparative epidemiology of Middle East respiratory syndrome coronavirus (MERS-CoV) in Saudi Arabia and South Korea Emerg Microbes Infect, 6 (2017), doi: 10.1038/emi.2017.40.

[12] C.R. MacIntyre, A.A. Chughtai, H. Seale, G.A. Richards, P.M. Davidson, Respiratory protection for healthcare workers treating Ebola virus disease (EVD): are face masks sufficient to meet occupational health and safety obligations?, Int. J. Nurs. Stud. 51 (2014), pp. 1421-1426. doi: 10.1016/j.ijnurstu.2014.09.002.

[13] International Monetary Fund (IMF), World economic outlook: the great lockdown, https://www.imf.org/en/Publications/WEO/Issues/2020/04/14/weo-april-2020. [accessed 10 May 2020]. 
[14] R. Djalante, J. Lassa, D. Setiamarga, et. al., Review and analysis of current responses to COVID-19 in Indonesia: Period of January to March 2020, Prog. in Disaster Sci. 6 (2020) 100091. doi: 10.1016/j.pdisas.2020.100091.

[15] Ministry of Health, Kementerian Kesehatan Republik Indonesia. https://www.kemkes.go.id/. [accessed 10 May 2020].

Kangle, Indonesia-Coronavirus. https://www.kaggle.com/ardisragen/indonesia coronavirus-cases. [accessed 10 May 2020].

[16] Croxford R. Continuous Predictors in Regression Analyses, SAS Global Forum. 2017. 